Sorption Behavior and Morphology of Plutonium in the Presence of Goethite at 25 and $80^{\circ} \mathrm{C}$

M. Zavarin, P. Zhao, Z. Dai, S. A. Carroll, A. B. Kersting

June 15, 2012 
This document was prepared as an account of work sponsored by an agency of the United States government. Neither the United States government nor Lawrence Livermore National Security, LLC, nor any of their employees makes any warranty, expressed or implied, or assumes any legal liability or responsibility for the accuracy, completeness, or usefulness of any information, apparatus, product, or process disclosed, or represents that its use would not infringe privately owned rights. Reference herein to any specific commercial product, process, or service by trade name, trademark, manufacturer, or otherwise does not necessarily constitute or imply its endorsement, recommendation, or favoring by the United States government or Lawrence Livermore National Security, LLC. The views and opinions of authors expressed herein do not necessarily state or reflect those of the United States government or Lawrence Livermore National Security, LLC, and shall not be used for advertising or product endorsement purposes.

This work performed under the auspices of the U.S. Department of Energy by Lawrence Livermore National Laboratory under Contract DE-AC52-07NA27344. 
This is a header

\title{
2. Sorption Behavior and Morphology of Plutonium in the Presence of Goethite at 25 and $80^{\circ} \mathrm{C}$
}

\author{
Mavrik Zavarin*, Pihong Zhao, Zurong Dai, Susan A. Carroll and Annie B. Kersting
}

* Glenn T. Seaborg Institute, Physical and Life Sciences Directorate, Lawrence Livermore National Laboratory, 7000 East Avenue, L-231, Livermore, California, 94551, USA

\section{$2.1 \quad$ Introduction}

Plutonium $(\mathrm{Pu})$ has been identified as a dominant long-term dose contributor under certain nuclear waste repository scenarios (Kaszuba and Runde, 1999; Office of Civilian Radioactive Waste Management, 2002). The transport of Pu will likely to occur by association with natural or anthropogenic colloids or as intrinsic colloids that migrate through the engineered barrier system and host rock. The dominant anthropogenic colloids may be iron oxides produced as a result of steel corrosion (Office of Civilian Radioactive Waste Management, 2002) or intrinsic colloids formed at relatively high actinide concentrations. The mineralogy of natural colloids will be a function of the host rock mineralogy or backfill material. Host rock minerals such as smectite and iron oxide are known to sorb Pu (Bertetti et al., 1998; Keeney-Kennicutt and Morse, 1985; Kozai et al., 1996; Kozai et al., 1993; Lujaniene et al., 2007; Powell et al., 2004, 2005; Powell et al., 2008; Sabodina et al., 2006; Sanchez et al., 1985; Turner et al., 1998), which will result in actinide immobilization or retention. However, actinide sorption to these same minerals, as colloids, may also result in colloid-facilitated transport (e.g. Kersting et al. (1999)).

A major challenge in predicting the mobility and transport of actinides in the natural environment is determining the dominant geochemical processes that control their transport behavior. The reaction chemistry of $\mathrm{Pu}$ (i.e., aqueous speciation, solubility, sorptivity, redox chemistry, and affinity for colloidal particles, both abiotic and microbially-mediated) is particularly complicated. Its migration is known to be oxidation-state dependent and facilitated by transport on particulate matter (i.e., colloidal particles). Despite the recognized importance of colloid-facilitated transport, little is known about the geochemical and biochemical mechanisms controlling Pu-colloid (intrinsic or pseudocolloid) formation and stability, particularly under relevant environmental conditions. At high concentrations $\left(>10^{-9} \mathrm{M}\right)$, $\mathrm{Pu}$ tends to form intrinsic nano-colloids (Neck et al., 2007); it is not known whether these nano-colloids are produced or are stable at very low (e.g. $\left.<10^{-9} \mathrm{M}\right)$ concentrations. Future radioactive waste repositories will likely involve environments at elevated temperatures. Thus, the effect of elevated temperature on the stability and sorptivity of monomeric and colloidal $\mathrm{Pu}$ is relevant as well.

The structure of $\mathrm{Pu}$ precipitates and nano-colloids has been investigated for many years, particularly from the standpoint of a sol-gel processes relevant to the production of dense forms of $\mathrm{PuO}_{2}$ (Lloyd and Haire, 1968). Early electron

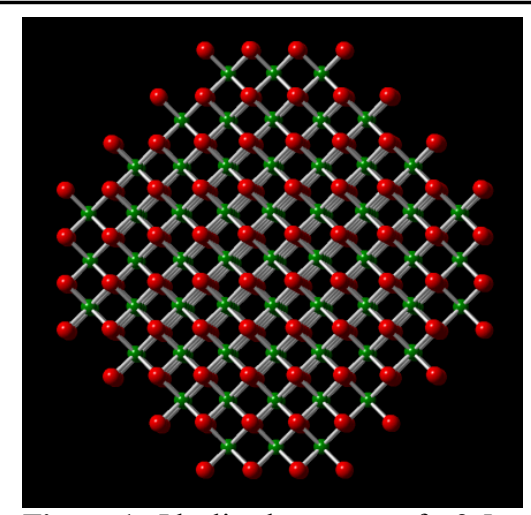

Figure 1. Idealized structure of a 2.5 $\mathrm{nm}$ fcc $\mathrm{PuO}_{2}$ nanoparticle. Each $\mathrm{Pu}(\mathrm{IV})$ atom (green) is in an octahedral position, surrounded by $\mathrm{O}$ atoms (red). microscopy studies by Haire et al. (1971) concluded that fresh $\mathrm{Pu}(\mathrm{IV})$ precipitates are composed of nanoparticles $<2.5 \mathrm{~nm}$ in size (Figure 1 ). The degree of crystallinity could be increased (based on x-ray diffraction line broadening) by ,aging“ the precipitates for a few hours in $<100^{\circ} \mathrm{C}$ water. However, the fundamental size of these nanoparticles is not affected. Importantly, these 
This is a header

nanoparticles were found to aggregate and were not considered stable in solution. Peptization (formation of a stable dispersion of $\mathrm{Pu}$ colloids in water) occurred when these precipitates were heated and reacted with $\sim 0.2 \mathrm{M} \mathrm{HNO}_{3}$. The colloidal products of this peptization have a $\mathrm{Pu}: \mathrm{NO}_{3}$ ratio of $\sim 1$. Larger crystallites $(4-10 \mathrm{~nm})$ could be produced only upon heating $\left(250^{\circ} \mathrm{C}\right.$ or greater $)$ which also reduced the $\mathrm{NO}_{3}{ }^{-} / \mathrm{Pu}$ ratio of the colloids from $\sim 1$ to $\sim 0.1$ (Lloyd and Haire, 1968).

More recently, Soderholm et al. (2008) examined the structure and formation of stable colloidal suspensions of $\mathrm{Pu}$ precipitates in $\mathrm{HCl} / \mathrm{LiCl}$ solutions. Upon evaporation from high salt solutions ( $2 \mathrm{M} \mathrm{LiCl})$, a novel precipitate was formed in which $\mathrm{PuO}_{2}$-like nano-clusters, „decorated“ by $\mathrm{Cl}^{-}$ anions, formed a crystalline superstructure (Figure 2). Unlike the earlier suggestions of Conradson et al. (2004), the presence of $\mathrm{H}_{2} \mathrm{O}$ of $\mathrm{OH}^{-}$or $\mathrm{Pu}(\mathrm{V}) \mathrm{O}_{2}{ }^{+}$in these nano-clusters was not identified. However, the stabilization of $\mathrm{Pu}$ sols in high ionic strength solutions is consistent with historical schemes developed as part of the sol-gel process. The unique scientific contribution of the Soderholm et al. (2008) work was the identification of well-ordered $\mathrm{Pu}$ nanoclusters that is in direct contrast to the traditional assumptions of poorly ordered polymeric or amorphous $\mathrm{Pu}(\mathrm{IV})$ precipitates. It also suggests that the $<2.5 \mathrm{~nm}$ sols produced by Haire et al. (1971) in dilute $\mathrm{HNO}_{3}$ with at $\mathrm{Pu}: \mathrm{NO}_{3}$ ratio of $\sim 1$ may be morphologically related to these nano-clusters $(\mathrm{Pu}: \mathrm{Cl}$ ratio of $0.7)$. However, the stability relationship between these nanoclusters and larger nano-colloids produced upon aging and heating of $\mathrm{Pu}(\mathrm{IV})$ precipitates/sols has yet to be understood.

The structure of $\mathrm{PuO}_{2}$ precipitates and colloids is complicated by the fact that $\mathrm{Pu}(\mathrm{IV})$ is susceptible to both reduction to $\mathrm{Pu}(\mathrm{III})$ and oxidation to $\mathrm{Pu}(\mathrm{V})$ and $\mathrm{Pu}(\mathrm{VI})$. Crystallographic studies of partially substituted $\mathrm{Pu}(\mathrm{IV}) \mathrm{O}_{2}$ precipitates has been the subject of ongoing research. Conradson et al. (2004) described the structural difference between $\mathrm{Pu}(\mathrm{IV}) \mathrm{O}_{2}$ and $\mathrm{Pu}(\mathrm{III})_{2} \mathrm{O}_{3}$ as an equivalent sublattice with $\mathrm{Pu}_{2} \mathrm{O}_{3}$ having one of four oxygen atoms removed from the basic $\mathrm{PuO}_{2}$ fluorite structure (Figure 3). Partial removal of oxygen atoms from $\mathrm{Pu}(\mathrm{IV}) \mathrm{O}_{2}$ can also produce an intermediate oxidation state precipitate, $\mathrm{Pu}_{4} \mathrm{O}_{7}$ (Petit et al., 2003).

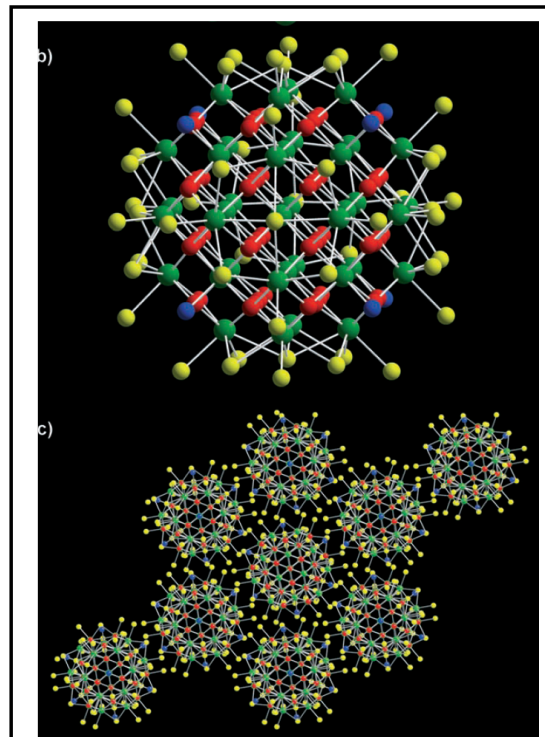

Figure 2. Structure and ordering of $\mathrm{Pu}(\mathrm{IV})$ nano-clusters formed in $\mathrm{LiCl}$ solution; the $\mathrm{PuO}_{2}$ framework exhibits a slightly distorted fcc packing of crystalline $\mathrm{PuO}_{2}$. Each $\mathrm{Pu}(\mathrm{IV})$ atom (green) is coordinated to $\mathrm{O}$ (red), $\mathrm{H}_{2} \mathrm{O}$ (blue), and/or $\mathrm{Cl}$ atoms that decorate the surface of the cluster (yellow). From Soderholm et al. (2010).

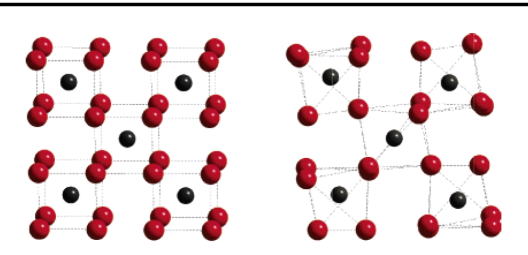

Figure 3. Comparison of ideal fluorite structure of $\mathrm{Pu}(\mathrm{IV}) \mathrm{O}_{2}$ and equivalent $\mathrm{Pu}(\mathrm{III})_{2} \mathrm{O}_{3}$ structure with one of four oxygen atoms removed. From Conradson et al. (2004).

A more controversial topic of ongoing research has been the structure of the partially oxidized form of $\mathrm{Pu}(\mathrm{IV}) \mathrm{O}_{2}$, namely $\mathrm{PuO}_{2+\mathrm{x}}$ (Conradson et al., 2004; Haschke et al., 2000; Penneman and Paffett, 2005; Petit et al., 2003). The position of the additional oxygen atoms was initially proposed to be in the octahedral vacancies in the fluorite structure. However, Conradson et al. (2004) characterized multiple preparations of $\mathrm{PuO}_{2+x}$ and determined that a more formal description of this phase should be $\mathrm{PuO}_{2+x-y}(\mathrm{OH})_{2 y}{ }^{*} \mathrm{zH}_{2} \mathrm{O}$ in which $\mathrm{OH}^{-}$and $\mathrm{H}_{2} \mathrm{O}$ are structurally incorporated into the $\mathrm{PuO}_{2}$ sublattice and the oxidized $\mathrm{Pu}$ is most likely $\mathrm{Pu}(\mathrm{V})$ with two $-\mathrm{yl}$ oxygens (Figure 4). This formulation was not observed in nano-clusters characterized by Soderholm et al. (2010). 
This is a header

In their recent work, Powell et al. (2011) examined the behavior of $\mathrm{Pu}(\mathrm{IV})$ surface precipitates and colloids in the presence of goethite and quartz. Transmission electron microscopy (TEM) was used to characterize the morphology of $\mathrm{Pu}$ associated with these mineral phases. Plutonium was added to goethite and quartz suspensions either as ,fresh“ (un-aged) $\mathrm{Pu}$ nano-colloids or as aqueous $\mathrm{Pu}(\mathrm{IV})$. Plutonium nano-colloids $(2-5 \mathrm{~nm})$ that formed on goethite from aqueous monomers underwent a lattice distortion relative to the ideal fluorite-type structure, fcc, $\mathrm{PuO}_{2}$, resulting in the formation of a bcc, $\mathrm{Pu}_{4} \mathrm{O}_{7}$. This structural distortion resulted from an epitaxial growth of the plutonium colloid on goethite, leading

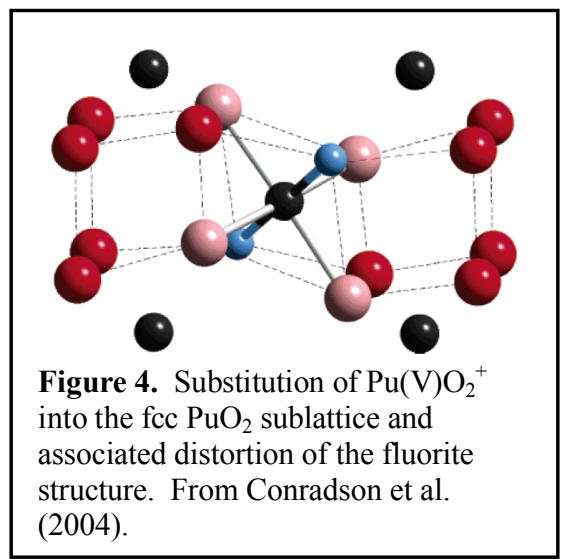
to stronger binding of plutonium compared with other minerals such as quartz where the distortion was not observed. Importantly, intrinsic $\mathrm{PuO}_{2}$ nano-colloids appeared to have a weak affinity for both goethite and quartz.

The results of Powell et al. (2011) and earlier studies suggest that the morphology, structure, and stability of $\mathrm{Pu}$ can vary dramatically and affect the sorptivity and mobility of $\mathrm{Pu}$ in the environment. An understanding of the stability of Pu nano-clusters and colloids and sorption/desorption kinetics of monomeric and colloidal $\mathrm{Pu}$ on common minerals is critical to predicting long-term colloid-facilitated transport behavior of $\mathrm{Pu}$ (Cvetkovic, 2000; Cvetkovic et al., 2004; Missana et al., 2004; Saiers and Hornberger, 1996; Steefel, 2008).

In this study, we examined the sorption behavior of $\mathrm{Pu}$ at elevated temperatures in the presence of one relevant mineral, goethite $(\alpha-\mathrm{FeOOH})$, over a range of concentrations that span solubilitycontrolled to adsorption-controlled concentrations. We focused on the sorptive behavior of two common forms of $\mathrm{Pu}$ : aqueous $\mathrm{Pu}(\mathrm{IV})$ and intrinsic $\mathrm{Pu}(\mathrm{IV})$ nano-colloids at 25 and $80^{\circ} \mathrm{C}$ in a dilute $\mathrm{pH} 8 \mathrm{NaCl} / \mathrm{NaHCO}_{3}$ solution. The morphology of Pu sorbed to goethite was characterized using transmission electron microscopy (TEM). We examined the relative stability of $\mathrm{PuO}_{2}$ precipitates, $\mathrm{PuO}_{2}$ nano-colloids, $\mathrm{Pu}_{4} \mathrm{O}_{7}$ surface precipitates, and monomeric sorbed $\mathrm{Pu}$ as a function of temperature and over a time scale of months.

\subsection{Materials and Methods}

Two series of batch sorption experiments were conducted. In the first series, aqueous $\mathrm{Pu}(\mathrm{IV})$ was reacted with goethite at 25 and $80^{\circ} \mathrm{C}$. The experiment was intended to test whether the affinity or morphology of sorbed $\mathrm{Pu}$ was temperature dependent. The experiment was performed under identical solution conditions used in an earlier $25^{\circ} \mathrm{C}$ sorption isotherm experiment $(0.1 \mathrm{~g} / \mathrm{L}$ goethite, $\mathrm{pH} 8,5 \mathrm{mM} \mathrm{NaCl} / 0.7 \mathrm{mM} \mathrm{NaHCO}_{3}$ ) (Zhao et al., 2010). However, in the present case, samples were equilibrated for three months rather than two weeks. Comparison of the present data to earlier isotherm data was used to evaluate the sorption kinetics and determine the stability of surface precipitates.

In the second set of experiments, intrinsic $\mathrm{Pu}(\mathrm{IV})$ nano-colloids were reacted with goethite at 25 and $80^{\circ} \mathrm{C}$. The intrinsic $\mathrm{Pu}(\mathrm{IV})$ nano-colloid sorption experiments were intended to test whether the initial form of $\mathrm{Pu}$ affects its longterm sorption behavior and evaluate the stability of $\mathrm{Pu}(\mathrm{IV})$ nano-colloids as a function of temperature.

At the end of the three month batch sorption experiments, Pu concentrations in the liquid phase were measured and compared to published,,amorphous" $\mathrm{PuO}_{2}\left(\mathrm{PuO}_{2}(\mathrm{am}, \mathrm{hyd})\right)$ solubility measurements (Neck et al., 2007) and sorption affinities (Zhao et al., 2010). In addition, a 
This is a header

detailed characterization of the $\mathrm{Pu}$ associated with the goethite mineral surface was conducted using TEM. The combination of liquid phase and surface characterization was used to evaluate the effect of temperature and the comparative behavior of aqueous $\mathrm{Pu}(\mathrm{IV})$ versus intrinsic nanocolloid $\mathrm{Pu}(\mathrm{IV})$ on $\mathrm{Pu}$ sorption characteristics.

\subsubsection{Pu stock solution}

Alpha-emitting ${ }^{242} \mathrm{Pu}$ ( $>99.8 \%$ by mass) was used in the experiments. The major isotopes contributing to alpha activities are ${ }^{238} \mathrm{Pu},{ }^{239,240} \mathrm{Pu}$ and ${ }^{242} \mathrm{Pu}$ with activity percentages of $15.9 \%$, $5.2 \%$ and $78.9 \%$, respectively. The Pu stock solution $\left(7.6 \times 10^{-4} \mathrm{M} \mathrm{Pu}(\mathrm{IV})\right.$ in $\left.2.06 \mathrm{M} \mathrm{HCl}\right)$ was purified using AG1x8 100-200 mesh anion exchange resin and filtered through a $3 \mathrm{kD}$ molecular weight cut-off (MWCO) filter. The oxidation state of $\mathrm{Pu}$ was confirmed using both UV/VIS and solvent extraction. The aqueous $\mathrm{Pu}(\mathrm{IV})$ working solution was prepared by diluting the stock solution to $1.9 \times 10^{-4} \mathrm{M} \mathrm{Pu}(\mathrm{IV})$ in $1 \mathrm{~N}$ $\mathrm{HCl}$. The intrinsic $\mathrm{Pu}(\mathrm{IV})$ nano-colloid working solutions was prepared by adding $1 \mathrm{~mL} 1 \mathrm{~N} \mathrm{NaOH}$ and $0.39 \mathrm{~mL} \mathrm{pH} 8$ buffer $\left(5 \mathrm{mM} \mathrm{NaCl} / 0.7 \mathrm{mM} \mathrm{NaHCO}_{3}\right.$ ) to $0.53 \mathrm{~mL}$ of the $\mathrm{Pu}(\mathrm{IV})$ stock. Another $0.06 \mathrm{~mL}$ of $1 \mathrm{~N} \mathrm{NaOH}$ was added gradually to adjust the $\mathrm{pH}$ to $\sim 8.5$. The final $\mathrm{Pu}(\mathrm{IV})$ nanocolloid concentration was $1.5 \times 10^{-4}$ and the $\mathrm{NaCl}$ electrolyte concentration was on the order of $1 \mathrm{M}$. The $\mathrm{Pu}(\mathrm{IV})$ nano-colloids were retained by $3 \mathrm{kD}$ MWCO filter. Thus, we estimate that the intrinsic nano-colloid size was generally $>1 \mathrm{~nm}$. Based on TEM, the fundamental particle size of intrinsic $\mathrm{Pu}$ nano-colloids prepared in this manner is $2-5 \mathrm{~nm}$ (Figure 5), somewhat larger than precipitate preparations by Haire et al. (1971) and nano-clusters of Soderhom et al. (2010). Aggregation of these intrinsic nano-colloids is commonly observed such that the aggregate size is larger (Powell et al., 2011).

\subsubsection{Goethite}

Goethite was synthesized from $\mathrm{Fe}\left(\mathrm{NO}_{3}\right)_{3} \bullet 9 \mathrm{H}_{2} \mathrm{O}$ as described by Schwertmann and Cornell (1991). Goethite was washed with a $5 \mathrm{mM} \mathrm{NaCl} / 0.7 \mathrm{mM} \mathrm{NaHCO}_{3}$ buffer solution, sonicated for 5 minutes, and centrifuged for 60 minutes at $3500 \mathrm{rpm}$ three times until constant $\mathrm{pH}$ was reached. Based on a spherical particle sedimentation estimate (Gee and Bauder, 1986), the goethite particle size retained was $>100 \mathrm{~nm}$. X-ray diffraction confirmed goethite as the major phase, the point of zero salt effect was $8.5 \pm 0.1$ and the BET surface area was $16 \mathrm{~m}^{2} / \mathrm{g}$. The predominant morphology of the geothite particles was ,star-shaped“. Additional characterization details can be found in Tinnacher et al.(2011).

\subsubsection{Batch Experiments}

All batch experiments were conducted in $10 \mathrm{~mL}$ Nalgene* Oak Ridge polycarbonate centrifuge tubes with sealing caps. Either aqueous $\mathrm{Pu}(\mathrm{IV})$ or intrinsic $\mathrm{Pu}(\mathrm{IV})$ nano-colloids were spiked into $9 \mathrm{~mL}$ of $5 \mathrm{mM} \mathrm{NaCl} / 0.7 \mathrm{mM} \mathrm{NaHCO}_{3}$ in which goethite (solid to liquid ratio of $0.1 \mathrm{~g} / \mathrm{L}$ ) had previously been added. Goethite-free Pu solutions were prepared in parallel. For the aqueous $\mathrm{Pu}(\mathrm{IV})$ experiments, an equivalent amount of $\mathrm{NaOH}$ was added before adding the $\mathrm{Pu}$ spike to ensure a final solution $\mathrm{pH}$ of 8 . The $10 \mathrm{~mL}$ tubes were submerged in $50 \mathrm{~mL}$ polypropylene conical centrifuge tubes filled with MQ water to minimize evaporative losses and provide secondary containment to the radioactive samples. Over the course of the experiment, the $25^{\circ} \mathrm{C}$ sample tubes were stored vertically in a hood. The $80^{\circ} \mathrm{C}$ sample tubes were submerged in a 
This is a header

heated water bath. Samples were periodically shaken and weighed to check for fluid evaporative losses; no significant loss of fluid was observed over the course of the experiment.

Three initial $\mathrm{Pu}$ concentrations were used (Table 1) such that the resulting equilibrium $\mathrm{Pu}$ concentration would be below, above, and near the $\mathrm{PuO}_{2}$ (am, hyd) solubility $\left(\sim 5 \times 10^{-9} \mathrm{M}\right)($ Neck et al., 2007). Two goethite-free solutions (spiked blanks) with initial $\mathrm{Pu}$ concentrations below and above $\mathrm{PuO}_{2}$ (am, hyd) solubility were used for comparison with sorption experiments. All solutions were allowed to react for 103 days.

At the conclusion of each experiment, two samples were taken from each tube. The first supernatant sample was taken after the goethite was allowed to settle out for $60 \mathrm{hrs}$. Based on sedimentation rates, we estimate that the supernatant included particles $<$ $\sim 250 \mathrm{~nm}$ on average (Table 2). The second supernatant sample was collected after centrifugation at 5000 rpm for 90 minutes at room temperature. In this case, the supernatant included particles $<\sim 25$ $\mathrm{nm}$ on average. Centrifugation was expected to effectively remove goethite particles. Sedimentation was also expected to remove the majority of goethite from solution. To test this, $\mathrm{Fe}$ in solution was monitored by ICP-MS. In all cases, Fe concentrations were low enough

\begin{tabular}{|c|c|c|c|}
\hline $\begin{array}{l}\text { Particle segregation } \\
\text { method }\end{array}$ & Particle & Temp. & $\begin{array}{l}\text { Particle size } \\
\text { cut-off }^{1}\end{array}$ \\
\hline & & ${ }^{\circ} \mathrm{C}$ & $\mathrm{nm}$ \\
\hline Sedimentation & Goethite & 25 & 375 \\
\hline Sedimentation & $\mathrm{PuO}_{2}$ (am, hyd) & 25 & 225 \\
\hline Sedimentation & Goethite & 80 & 250 \\
\hline Sedimentation & $\mathrm{PuO}_{2}$ (am, hyd) & 80 & 125 \\
\hline Centrifugation & Goethite & 25 & 35 \\
\hline Centrifugation & $\mathrm{PuO}_{2}(\mathrm{am}, \mathrm{hyd})$ & 25 & 19 \\
\hline \multicolumn{4}{|c|}{$\begin{array}{l}\text { 'Sedimentation rates were calculated using goethite and } \mathrm{PuO}_{2} \\
\text { densities of } 4.27 \text { and } 11.5 \mathrm{~g} / \mathrm{cm}^{3} \text {. Fluid viscosity used at } 25 \text { and } \\
80^{\circ} \mathrm{C} \text { were } 8.90 \times 10^{-4} \text { and } 3.55 \times 10^{-4} \text {, respectively. The fluid } \\
\text { density used at } 25 \text { and } 80^{\circ} \mathrm{C} \text { was } 0.997 \text { and } 0.972 \mathrm{~g} / \mathrm{cm}^{3} \text {, } \\
\text { respectively. Sedimentation was rounded to the nearest } 25 \mathrm{~nm} \text {. }\end{array}$} \\
\hline
\end{tabular}
such that the contribution of goethite to the measured $\mathrm{Pu}$ solution concentration was predicted to be negligible ( $<0.2 \%$ of $\mathrm{Pu}$ in solution). Neither sedimentation nor centrifugation was expected to quantitatively remove dispersed $\mathrm{Pu}(\mathrm{IV})$ nano-colloids from solution. However, centrifugation would likely remove most aggregated nano-colloids. A comparison of the sedimentation and centrifugation supernatants provides information on the presence of intermediate-sized $\mathrm{Pu}$ colloid aggregates in solution $(25-250 \mathrm{~nm})$.

\subsubsection{Pu analysis}

Both liquid scintillation counting (LSC) and ICP-MS were used to determine Pu concentration. The LSC was used for samples with high $\mathrm{Pu}$ and ICP-MS used for samples in which $\mathrm{Pu}$ concentrations were below the LSC method detection limit $\left(\sim 3 \times 10^{-10} \mathrm{M}\right)$. It is important to consider the fact that sedimentation and centrifugation only segregate particles greater than the associated particle size cut off. Thus, the measured $\mathrm{Pu}$ concentration in solution represents both aqueous $\mathrm{Pu}$ and $\mathrm{Pu}$ nano-colloids (or aggregates) smaller than the cutoff size for sedimentation or centrifugation (i.e. Table 2).
Table 1. Experimental conditions for $\mathrm{Pu}(\mathrm{IV})$

\begin{tabular}{lcc}
\hline Pu form & Initial Pu & $\begin{array}{c}\text { Goethite } \\
\text { conc. }\end{array}$ \\
\hline Aqueous & $7.3 \times 10^{-11}$ & $\mathrm{~g} / \mathrm{L}$ \\
Aqueous & $8.0 \times 10^{-7}$ & 0 \\
Colloidal & $9.6 \times 10^{-11}$ & 0 \\
Colloidal & $7.3 \times 10^{-7}$ & 0 \\
\hline Aqueous & $3.8 \times 10^{-9}$ & 0.1 \\
Aqueous & $7.8 \times 10^{-7}$ & 0.1 \\
Aqueous & $3.8 \times 10^{-6}$ & 0.1 \\
Colloidal & $3.1 \times 10^{-8}$ & 0.1 \\
Colloidal & $7.3 \times 10^{-7}$ & 0.1 \\
Colloidal & $3.7 \times 10^{-6}$ & 0.1 \\
\hline & &
\end{tabular}
samples at 25 and $80^{\circ} \mathrm{C}$ 


\subsubsection{TEM Sample Preparation and Analysis}

This is a header

At the conclusion of each experiment, the solid phases were washed in MQ ( $>18 \mathrm{M} \Omega)$ water three times by sequentially centrifuging at $5000 \mathrm{rpm}$ for 90 minutes, decanting the supernatant, and replacing it with fresh MQ water. The washing was performed to remove salts from solution. The solids were re-suspended in MQ water by sonicating for 5 minutes and diluting $10 \times$ to produce a $0.01 \mathrm{~g} / \mathrm{L}$ suspension. A volume of 2 to $5 \mathrm{uL}$ of each suspension was deposited on TEM carbon-coated copper grids and dried in a glass desiccator. All analyses were performed on a Philips CM 300 FEG TEM operating at $300 \mathrm{kV}$ and equipped with a Gatan Imaging Filter (GIF) with a $2 \mathrm{k} \times 2 \mathrm{k}$ CCD camera and an EDX detector.

\subsection{Results and Discussion}

\subsubsection{Pu behavior in the absence of goethite}

Spiked-blanks (i.e. goethite-free solutions) were run to examine homogeneous precipitation of $\mathrm{PuO}_{2}$ (am, hyd) and potential loss of $\mathrm{Pu}$ to container walls. Both aqueous $\mathrm{Pu}(\mathrm{IV})$ and intrinsic $\mathrm{Pu}(\mathrm{IV})$ nano-colloid solutions were equilibrated for 103 days at 25 and $80^{\circ} \mathrm{C}$; initial $\mathrm{Pu}$ concentrations were either oversaturated $\left(\sim 10^{-6} \mathrm{M}\right)$ or undersaturated $\left(\sim 10^{-10} \mathrm{M}\right)$ with respect to $\mathrm{PuO}_{2}$ (am, hyd). The solution concentration data, superimposed on the $\mathrm{PuO}_{2}$ (am, hyd) solubility data presented in Neck et al. (2007), are presented in Figure 6.

For all undersaturated samples, $\mathrm{Pu}$ in solution was similar (sedimentation and centrifugation produced equivalent concentrations) after 103 days $\left(\sim 10^{-11} \mathrm{M}\right)$. The initial form of $\mathrm{Pu}(\mathrm{IV})$ and temperature do not appear to have an appreciable effect on $\mathrm{Pu}$ concentrations in solution. However, whether $\mathrm{Pu}(\mathrm{IV})$ nano-colloids dissolved or remained dispersed in solution cannot be distinguished. Significant losses of $\mathrm{Pu}$ from solution did occur (70-90\%). We attribute these losses to sorption to container walls, as is commonly observed. Loss of $\mathrm{Pu}$ as a result of precipitation and/or aggregation of $\mathrm{Pu}$ nano-colloids is not thermodynamically favored at these concentrations.

In all high concentration $\left(\sim 10^{-6} \mathrm{M}\right)$ samples, the $\mathrm{Pu}$ concentration remaining in solution is consistent with the range of $\mathrm{PuO}_{2}\left(\mathrm{am}\right.$, hyd) solubility at $25^{\circ} \mathrm{C}$ as reported in Neck et al. (2007). Neck et al. (2007) found that a mixture of colloidal $\mathrm{PuO}_{2}$ and aqueous $\mathrm{Pu}(\mathrm{V})$ are the predominant forms of $\mathrm{Pu}$ in solution under these conditions. However, the concentration of colloidal $\mathrm{PuO}_{2}$ is conditional, depending on the choice of particle size range that is considered

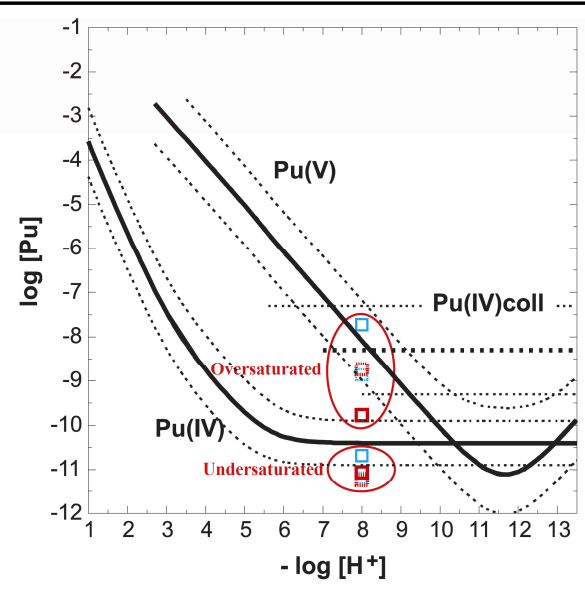

$\square$ Sample initially spiked with Pu(IV), $25^{\circ} \mathrm{C}$ Sample initially spiked with intrinsic Pu(IV) nano-colloids, $25^{\circ} \mathrm{C}$

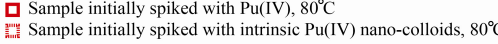

Figure 6. Pu concentrations in eight goethitefree spiked blanks oversaturated (initially $\sim 10^{-6}$ $\mathrm{M})$ and undersaturated (initially $10^{-10} \mathrm{M}$ ) with respect to $\mathrm{PuO}_{2}$ (am, hyd). Data are superimposed over $\mathrm{PuO}_{2}$ (am, hyd) solubility data reported in Figure 5 from Neck et al. (2007). Pu concentrations in supernatants from sedimentation and centrifugation samples yielded similar results.

"colloidal". In the case of Neck et al. (2007), the colloidal fraction was defined as the fraction collected by a $10 \mathrm{kD}(\sim 1.5 \mathrm{~nm}$ pore size $)$ filter from a "clear supernatant". Thus, the upper limit of the particle size considered "colloidal" is not strictly defined. In our case, the sedimentation results in a particle size upper limit estimate of $\sim 250 \mathrm{~nm}$ for the solution phase. A higher upper limit would tend to increase the apparent $\mathrm{Pu}$ concentration in solution. 
This is a header

Intrinsic $\mathrm{Pu}(\mathrm{IV})$ nano-colloids "precipitated" from solution ( $99.7 \%)$ in equal amounts at both temperatures. The "precipitation" is, in reality, an aging and aggregation process (Figure 5) in which $\mathrm{PuO}_{2}$ nano-colloids retain their original crystallite size $(2-5 \mathrm{~nm})$. Importantly, these crystalline nano-colloids are larger than the nano-clusters identified by Soderholm et al. (2008) and may reflect the growth of nano-clusters to larger crystalline nano-colloids at low ionic strengths and high $\mathrm{pH}$ over time. The formation of $\mathrm{Pu}-\mathrm{Cl}$ ionic bonding, for $\mathrm{Pu}(\mathrm{IV})$ monomers, is predicted to occur only at very low $\mathrm{pHs}(<1)$ where formation of hydrolysis species is not favored (Guillaumont et al., 2003). Thus, the stability of $\mathrm{Cl}^{-}$-containing nano-clusters (Sorderholm et al., 2008) or high $\mathrm{NO}_{3}{ }^{-}$sols (Haire et al., 1971) is likely to be electrolyte concentration and $\mathrm{pH}$ dependent.

The behavior of aqueous $\mathrm{Pu}(\mathrm{IV})$ is temperature-dependent. At 103 days, the $\mathrm{Pu}$ concentration at $80^{\circ} \mathrm{C}$ was two orders of magnitude lower than at $25^{\circ} \mathrm{C}$ (Figure 6). Precipitation at high temperatures leads to lower apparent solubilities which reflect greater aggregation of colloidal precipitates. In contrast aggregation of pre-formed $\mathrm{PuO}_{2}$ nano-colloids at high temperatures is not as effective. This implies that colloid formation and aggregation processes are irreversible. This is likely the reason why $\mathrm{Pu}(\mathrm{IV})$ colloid solubility measurements reported in Neck et al. (2007) are uncertain $(\log \mathrm{K}=8.3 \pm 1.0)$

\subsubsection{Pu behavior in the presence of goethite}

Figure 7 presents the sorption of aqueous $\mathrm{Pu}(\mathrm{IV})$ and intrinsic $\mathrm{Pu}(\mathrm{IV})$ nano-colloids to goethite at $25^{\circ} \mathrm{C}$. For each form of $\mathrm{Pu}$, data at three concentrations are presented. For simplicity, we designate these as low, intermediate, and high concentration samples. For comparison, Figure 7 also includes earlier aqueous $\mathrm{Pu}(\mathrm{IV})$ isotherm data at 7 and 14 days from an experiment performed over a much wider $\mathrm{Pu}(\mathrm{IV})$ concentration range while using the identical mineral and solution conditions (Zhao et al., 2010). Solution concentration data (and associated solid concentrations) are presented based on measured $\mathrm{Pu}$ supernatant concentrations after sedimentation (approximately $<250 \mathrm{~nm}$ ) and centrifugation (approximately $<25$ $\mathrm{nm}$ ) procedures (Table 2). Based on ICPMS measurements of Fe in solution, goethite was effectively removed. Thus, differences between measured $\mathrm{Pu}$

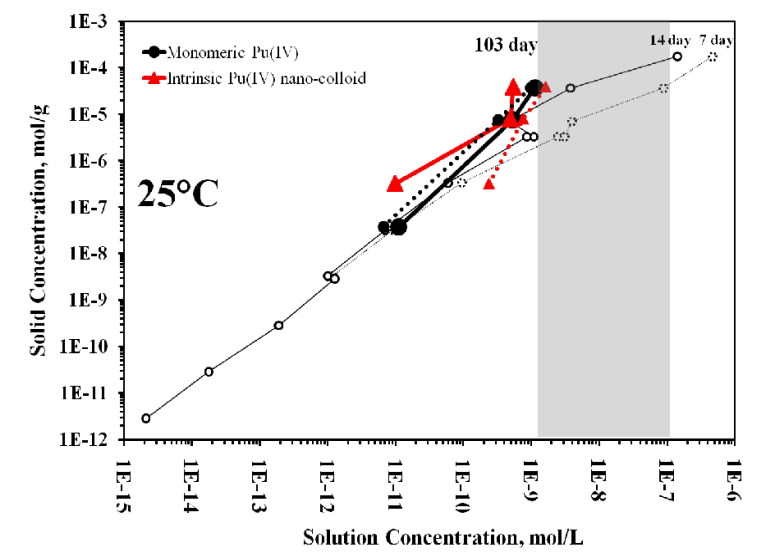

Figure 7. Sorption of aqueous $\mathrm{Pu}(\mathrm{IV})$ (black) and intrinsic $\mathrm{Pu}(\mathrm{IV})$ nano-colloids (red) to goethite at $25^{\circ} \mathrm{C}$. Aqueous concentration based on sedimentation $(<250 \mathrm{~nm}$, dashed line) and centrifugation $(<25 \mathrm{~nm}$, solid line). The 7 day and 14 day aqueous $\mathrm{Pu}(\mathrm{IV})$ sorption experiments (small black circles) were performed earlier under identical solution conditions. Gray zone is estimated total $\mathrm{Pu}$ concentration in equilibrium with $\mathrm{PuO}_{2}$ (am, hyd) reported in (Neck et al., 2007) at $\mathrm{pH} 8$. supernatant concentrations from these two procedures are an indication that $\mathrm{Pu}$ is present in substantial quantities associated with aggregated $\mathrm{PuO}_{2}$ nano-particles in the $25-250 \mathrm{~nm}$ range.

The present aqueous $\mathrm{Pu}(\mathrm{IV})$ sorption data are in excellent agreement with the earlier isotherm data. The low concentration aqueous $\mathrm{Pu}(\mathrm{IV})$ sample matches previous data (small black symbols), indicating that equilibrium sorption was reached within 7 days. The low concentration sorption represents monomeric adsorption of $\mathrm{Pu}(\mathrm{IV})$ to the goethite surface. The intermediate concentration aqueous $\mathrm{Pu}(\mathrm{IV})$ sample matches the previous data at 14 days, indicating that sorption/surface precipitation reached equilibrium within 14 days. The highest concentration 
This is a header

aqueous $\mathrm{Pu}(\mathrm{IV})$ sample $\left(1.1 \mathrm{x} \mathrm{E}^{-9} \mathrm{M}\right)$ resulted in a solution concentration lower than the earlier 14 day sample, $\left(3.8 \times 10^{-9} \mathrm{M}\right)$ indicating that equilibrium had not been reached within 14 days. For the intermediate and high aqueous $\mathrm{Pu}(\mathrm{IV})$ concentration samples, solubility considerations suggest that precipitation of $\mathrm{PuO}_{2}$ (am, hyd) will occur (initial Pu concentrations were $8 \times 10^{-7}$ and $4 \times 10^{-6} \mathrm{M}$, respectively, Table 1). Equilibrium solution concentrations are slightly lower than expected based on thermodynamic estimates alone (see Figure 4). However, the Pu concentration in solution may be lower simply because the particle size range to which the "colloidal" fraction was attributed $(<250 \mathrm{~nm})$ is smaller than that used by Neck et al. (2007).

The behavior of intrinsic $\mathrm{Pu}(\mathrm{IV})$ nano-colloids differs significantly from that of aqueous $\mathrm{Pu}(\mathrm{IV})$ only in the low concentration sample. A substantial difference between $\mathrm{Pu}$ concentration in solution after sedimentation $\left(2.4 \times 10^{-10} \mathrm{M}\right)$ versus centrifugation $\left(9.8 \times 10^{-12} \mathrm{M}\right)$ indicates that large $(25-250 \mathrm{~nm})$ aggregated intrinsic $\mathrm{Pu}(\mathrm{IV})$ nano-colloids are present and do not have a strong affinity for the goethite surface. It suggests that intrinsic $\mathrm{Pu}(\mathrm{IV})$ nano-colloids at low concentrations may not be subject to sorption processes that would retard their migration.

However, the intermediate and high concentration samples do not exhibit this same behavior. The intermediate and high concentration intrinsic $\mathrm{Pu}(\mathrm{IV})$ nano-colloid sorption samples result in solution concentrations similar to aqueous $\mathrm{Pu}(\mathrm{IV})$ sorption samples, driven by aggregation processes that can be categorized as precipitation.

Figure 8 presents the $80^{\circ} \mathrm{C}$ sorption data for aqueous $\mathrm{Pu}(\mathrm{IV})$ and intrinsic $\mathrm{Pu}(\mathrm{IV})$ nanocolloids. The $80^{\circ} \mathrm{C}$ aqueous $\mathrm{Pu}(\mathrm{IV})$ sorption data are similar to the $25^{\circ} \mathrm{C}$ data. However, greater differences in solution $\mathrm{Pu}$ concentrations between sedimentation and centrifugation suggest that large $25-250 \mathrm{~nm}$ aggregated intrinsic $\mathrm{Pu}(\mathrm{IV})$ nano-colloids may be more stable and prevalent at higher temperatures. Haire et al. (1971) also found that temperature will increase the stability of colloidal $\mathrm{PuO}_{2}$ in solution.

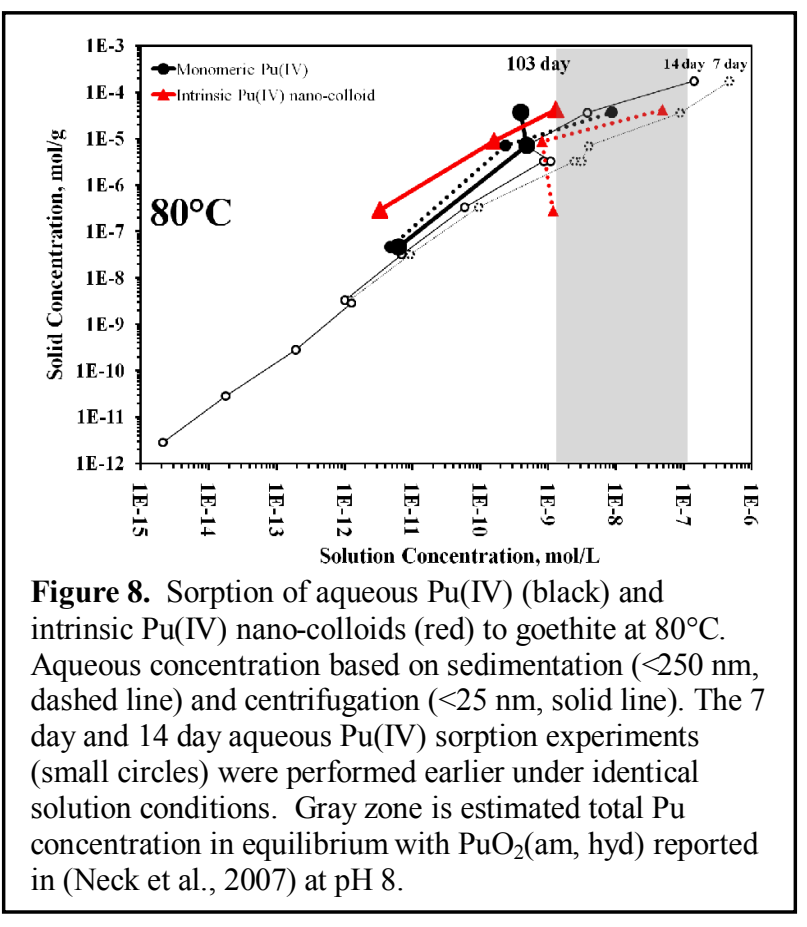

\subsubsection{TEM observation of Pu morphology}

\subsubsection{Aqueous $\mathrm{Pu}$ on goethite, $25^{\circ} \mathrm{C}$}

In the presence of goethite and at $25^{\circ} \mathrm{C}$, aqueous $\mathrm{Pu}(\mathrm{IV})$ has been shown to grow epitaxially, forming bcc $\mathrm{Pu}_{4} \mathrm{O}_{7}$ nano-colloids in the $2-5 \mathrm{~nm}$ particle size range (Powell et al., 2011). While previous observations were made on samples reacted for short durations, the $\mathrm{Pu}_{4} \mathrm{O}_{7}$ nano-colloids appear to be stable over the longer experiment timeframe examined here (103 days). Importantly, this indicates that the $\mathrm{Pu}_{4} \mathrm{O}_{7}$ is stable on the goethite surface and will not alter to a $\mathrm{PuO}_{2}$ phase over a timeframe of months. 
This is a header

Identification of $\mathrm{PuO}_{2}$ versus $\mathrm{Pu}_{4} \mathrm{O}_{7}$ on the goethite surface was accomplished by examining HRTEM FFT patters (Figure 9).

However, we have also found that the two forms exhibit distinct morphological characteristics at the nanoscale. In general, $\mathrm{PuO}_{2}$ nano-particles form aggregates that range in size from tens to hundreds of nanometers while $\mathrm{Pu}_{4} \mathrm{O}_{7}$

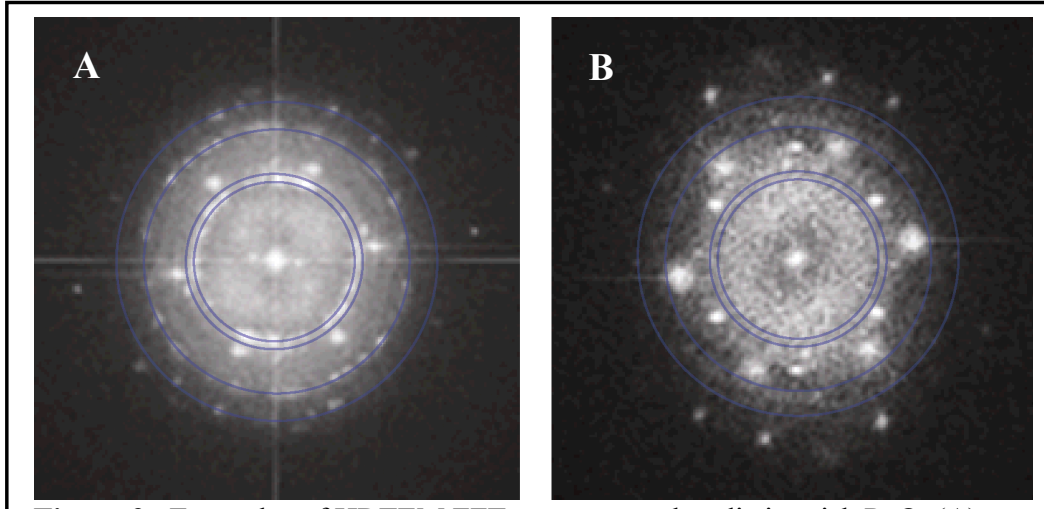

Figure 9. Examples of HRTEM FFT patterns used to distinguish $\mathrm{PuO}_{2}(\mathrm{~A})$ from $\mathrm{Pu}_{4} \mathrm{O}_{7}$ (B) nanoparticles on goethite. Diffraction pattern characteristic of $\mathrm{PuO}_{2}$ (blue lines) is superimposed on both images for emphasis.

nano-particles are uniquely associated with the goethite surface and distributed as dispersed 2-5 $\mathrm{nm}$ nano-particles. These morphologies are illustrated in the following discussion.

In the intermediate concentration sample, $\mathrm{Pu}_{4} \mathrm{O}_{7}$ nano-colloids are widely distributed over the goethite surface and dominated by isolated (dispersed) $2-5 \mathrm{~nm}$ nano-colloids (Figure 10). In the high concentration sample, both dispersed $\mathrm{Pu}_{4} \mathrm{O}_{7}$ nano-colloids and aggregated fcc $\mathrm{PuO}_{2}$ nano-

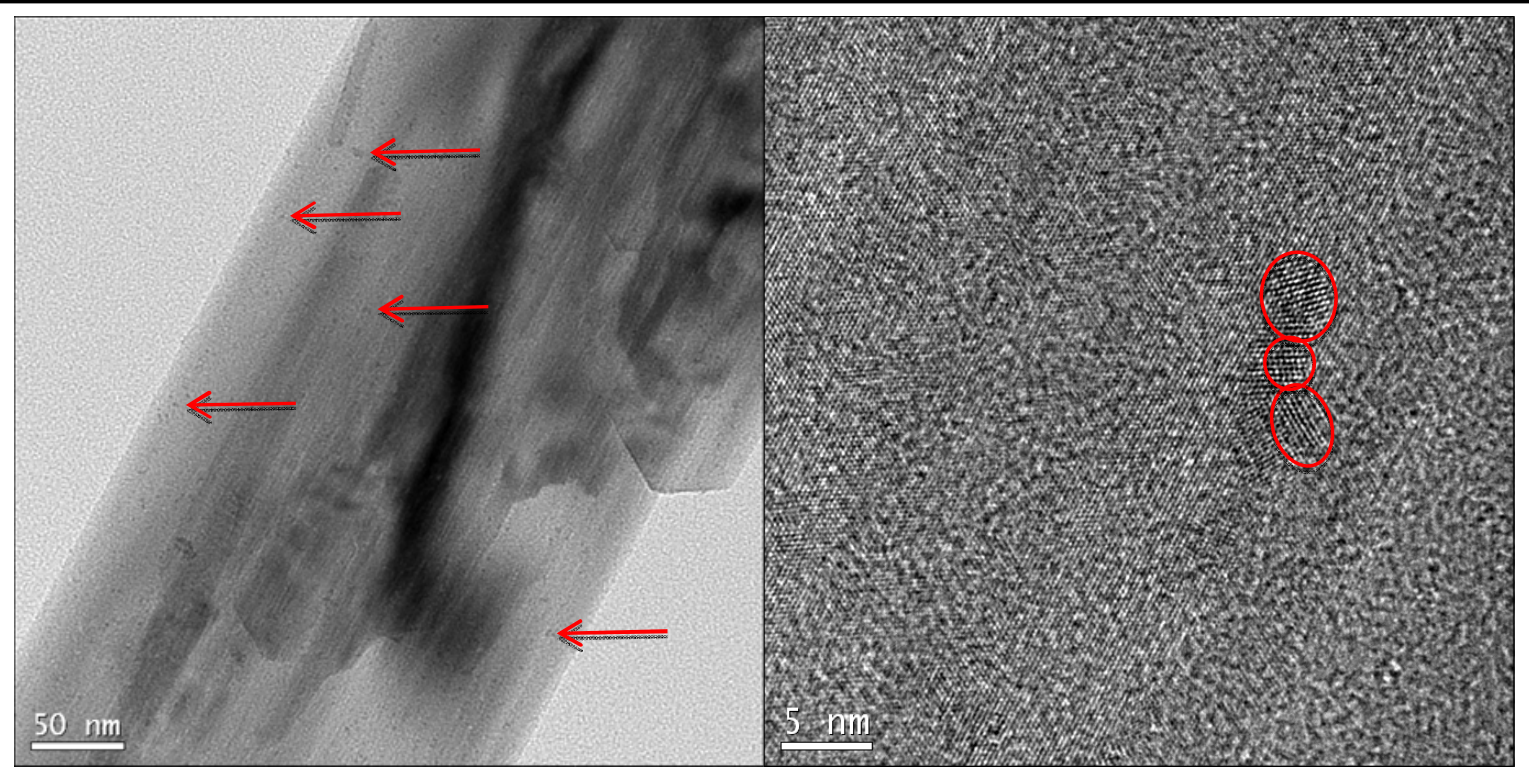

Figure 10. Dispersed $\mathrm{Pu}_{4} \mathrm{O}_{7}$ on the goethite surface retains its 2-5 nm particle size after 3 months of equilibration at $25^{\circ} \mathrm{C}$. Large aggregates and/or alteration to $\mathrm{PuO}_{2}$ was not observed. $1800 \mathrm{ppm} \mathrm{Pu}$ on goethite.

colloids exist (Figure 11). Importantly, the fundamental crystalline size remains in the $2-5 \mathrm{~nm}$ size range for both forms of Pu nano-colloid and in all samples. In the high concentration sample, nano-colloid aggregation is more pronounced. It cannot be ascertained whether this aggregation is purely a physical/electrostatic interaction or a chemical one. However, that difference may have a pronounced effect on the transport behavior of intrinsic $\mathrm{Pu}$ nano-colloids as well as the transport behavior facilitated by iron oxide colloids. Importantly, aggregated nanocolloids appear to be dominated by $\mathrm{PuO}_{2}$ nano-colloids precipitated directly from solution and weakly associated with the goethite surface. From a bulk solution standpoint, this would be 
This is a header

characterized as precipitation of $\mathrm{PuO}_{2}$ (am, hyd). At the nanoscale, it is characterized as aggregation of $\mathrm{PuO}_{2}$ nano-colloids.

\subsubsection{Intrinsic Pu nano-colloids on goethite, $25^{\circ} \mathrm{C}$}

Unlike aqueous $\mathrm{Pu}(\mathrm{IV})$ sorption, intrinsic $\mathrm{Pu}$ (IV) nano-colloids sorption to goethite is dominated by aggregated mats of $\mathrm{PuO}_{2}$ nano-colloids. These mats were observed in both the intermediate and high concentration samples (Figure 12). The $\mathrm{Pu}_{4} \mathrm{O}_{7}$ colloids that were observed in the aqueous $\mathrm{Pu}$-experiments were not observed in any of the intrinsic $\mathrm{Pu}$ colloid experiments. Importantly, this indicates that the $\mathrm{PuO}_{2}$ colloids, once formed, will not alter to $\mathrm{Pu}_{4} \mathrm{O}_{7}$ over a timeframe of months. In addition, however, the ordered $\mathrm{PuO}_{2}$ does not appear to grow beyond its initial $2-5 \mathrm{~nm}$

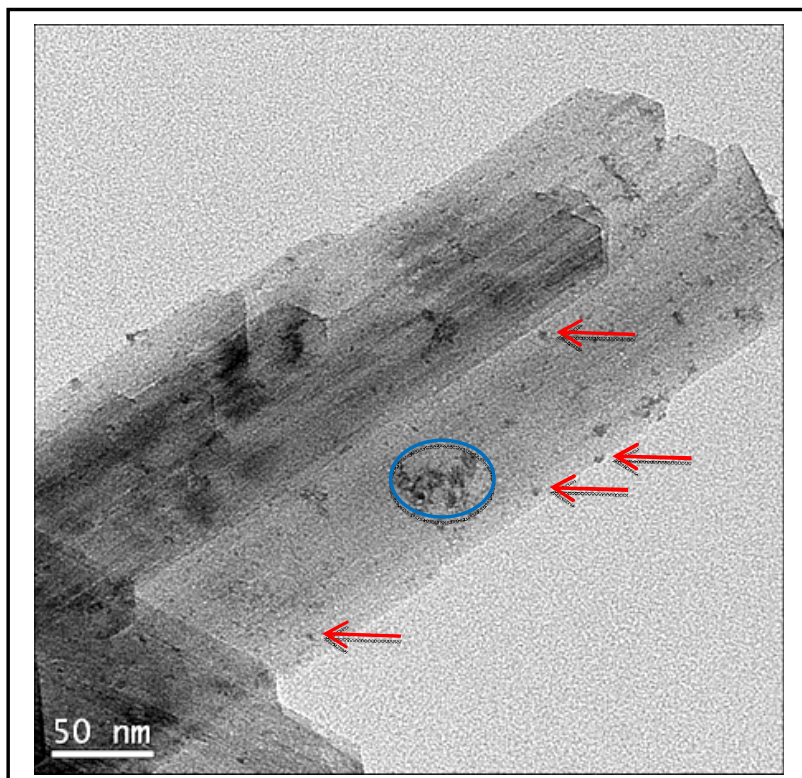

Figure 11. Both $\mathrm{PuO}_{2}$ aggregates (blue) and dispersed $\mathrm{Pu}_{4} \mathrm{O}_{7}$ (red) on the goethite surface was observed at $25^{\circ} \mathrm{C}$ in high concentration samples. $8900 \mathrm{ppm} \mathrm{Pu}$ on goethite. crystalline size, consistent with previous work (Haire et al., 1971).

Because these mats are located both on and off goethite (Figure 12B and C), it is clear that the interaction between intrinsic $\mathrm{PuO}_{2}$ nano-colloids and the goethite surface is much weaker than in the case of aqueous $\mathrm{Pu}(\mathrm{IV})$ sorption. The bulk solution chemistry data (Figure 3 ) suggest that the same weak interaction between $\mathrm{PuO}_{2}$ nano-colloids and goethite exist at the low $\mathrm{Pu}$ concentration. However, identification of $\mathrm{PuO}_{2}$ colloids by TEM at low surface loading is exceedingly difficult (the needle in the haystack problem). It was not attempted for the low concentration sample. 
This is a header

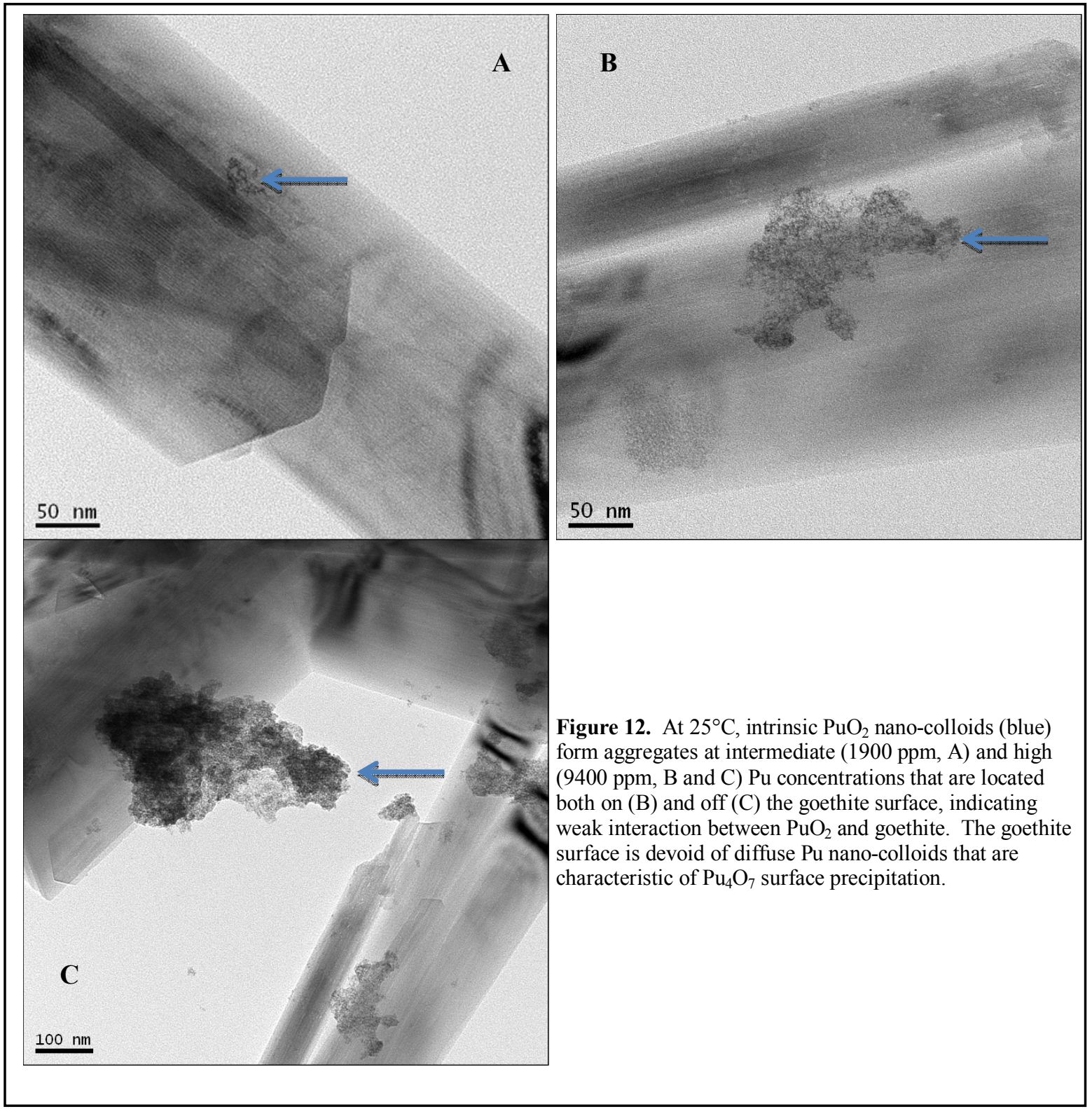

\subsubsection{Aqueous $\mathrm{Pu}$ on goethite, $80^{\circ} \mathrm{C}$}

The characteristics of $\mathrm{Pu}$ associated with goethite at $80^{\circ} \mathrm{C}$ are not substantially different from those at $25^{\circ} \mathrm{C}$. The intermediate concentration aqueous $\mathrm{Pu}(\mathrm{IV})$ sample is dominated by dispersed $\mathrm{Pu}_{4} \mathrm{O}_{7}$ nano-colloids that are in the $2-5 \mathrm{~nm}$ size range (Figure 13). In the high concentration sample, both aggregated $\mathrm{PuO}_{2}$ nano-colloids and dispersed $\mathrm{Pu}_{4} \mathrm{O}_{7}$ nano-colloids are present. The aggregated $\mathrm{PuO}_{2}$ nano-colloids are located both on and off the goethite surface while the $\mathrm{Pu}_{4} \mathrm{O}_{7}$ nano-colloids are strictly associated with the goethite surface. At $80^{\circ} \mathrm{C}$, the size of the aggregated $\mathrm{PuO}_{2}$ nano-colloids appears to be larger. This is consistent with $\mathrm{Pu}$ concentrations measured in solution (Figure 5) which suggest a significant fraction of intrinsic $\mathrm{Pu}(\mathrm{IV})$ nano-colloids are aggregated and in the $25-250 \mathrm{~nm}$ particle size range. 


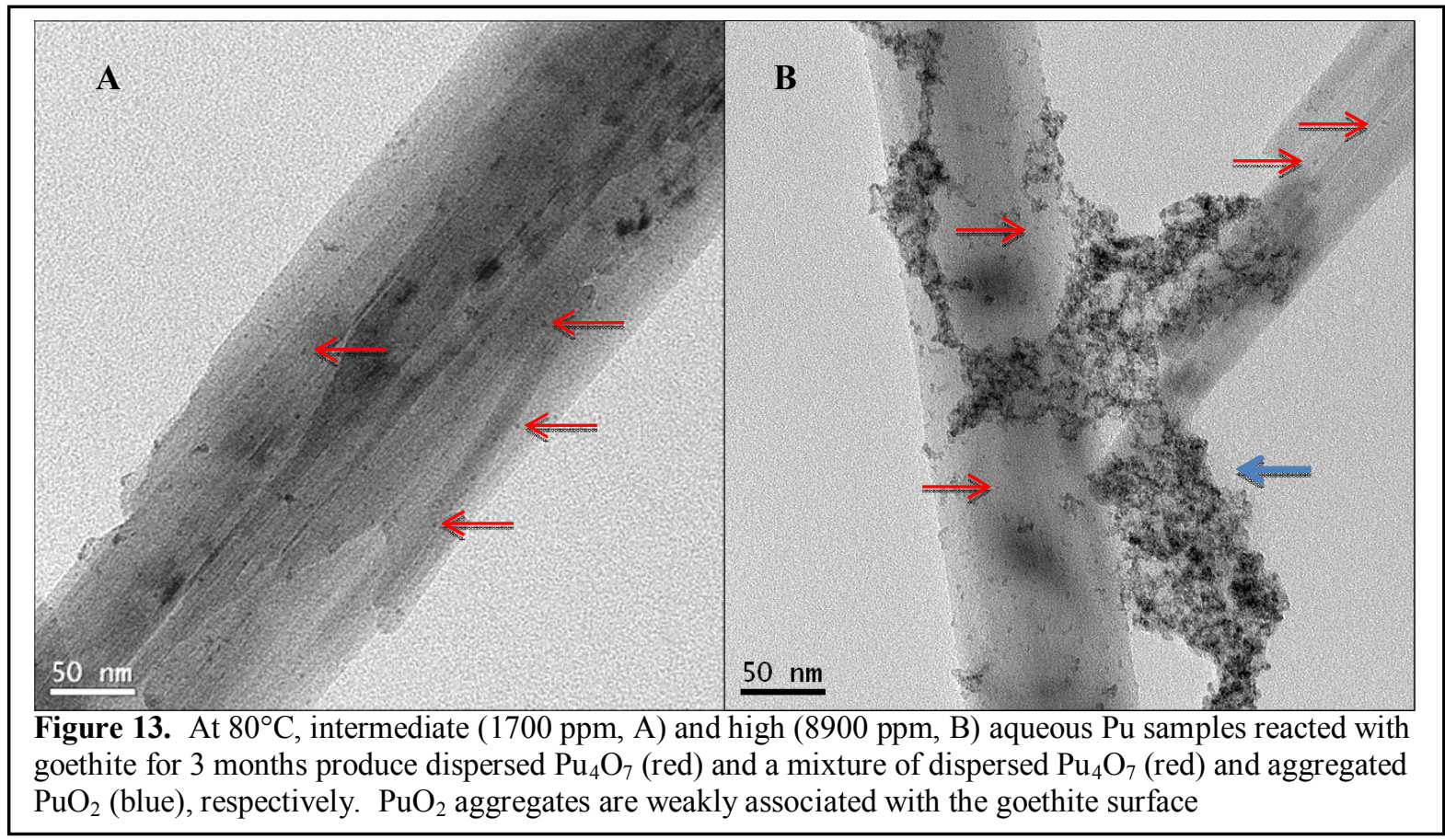

\subsubsection{Intrinsic Pu nano-colloids on goethite, $80^{\circ} \mathrm{C}$}

The behavior of intrinsic $\mathrm{Pu}(\mathrm{IV})$ nano-colloids at $80^{\circ} \mathrm{C}$ is dominated in both intermediate and high concentration samples by the formation of large aggregated $\mathrm{PuO}_{2}$ nano-colloids and little if any association with the goethite surface (Figures 14). In terms of bulk solution chemistry, these would be considered precipitates of $\mathrm{PuO}_{2}(\mathrm{am}$, hyd). HRTEM images and electron diffraction analysis indicate that the mats are composed of 2-5 nm nano-colloids with a fcc $\mathrm{PuO}_{2}$ structure. Importantly, the results suggest that the relationship between colloidal and precipitated forms of $\mathrm{PuO}_{2}$ (am, hyd) is controlled by degree of aggregation of 2-5 nm nano-colloids. Aggregation of nano-colloids is controlled primarily by the solution conditions in which they are present $(\mathrm{Pu}$ concentration, solution composition (e.g. ionic strength, $\mathrm{pH}$ ) and temperature). Thus, the concentration of dispersed intrinsic $\mathrm{PuO}_{2}$ nano-colloids in solution will most likely be controlled by the physical aggregation behavior of $\mathrm{PuO}_{2}$ nano-colloids.

\subsection{Conclusions}

The strong affinity of aqueous $\mathrm{Pu}(\mathrm{IV})$ for the goethite surface is explained by the epitaxial growth of bcc $\mathrm{Pu}_{4} \mathrm{O}_{7}$ nano-colloids on goethite. The behavior is affected minimally by temperature. However, the dispersed 2-5 $\mathrm{nm} \mathrm{Pu}_{4} \mathrm{O}_{7}$ on the goethite surface appears to be stable over the timescale of months at both 25 and $80^{\circ} \mathrm{C}$. There is no indication that the $\mathrm{Pu}_{4} \mathrm{O}_{7}$ alters to a more stable $\mathrm{PuO}_{2}$ nano-colloid over time. When intrinsic $\mathrm{PuO}_{2}$ nano-colloids are reacted with goethite over 103 days, both solution phase characterization in low concentration samples and TEM of high concentration samples indicate that the $\mathrm{PuO}_{2}$ nano-colloids have a very weak affinity for the goethite surface. Importantly, there is no indication that the $\mathrm{PuO}_{2}$ will alter to a more stable $\mathrm{Pu}_{4} \mathrm{O}_{7}$ nano-colloid on the goethite surface over time. Thus it appears that the association of $\mathrm{Pu}$ to goethite is dependent on the initial state of $\mathrm{Pu}$ in solution. 
This is a header

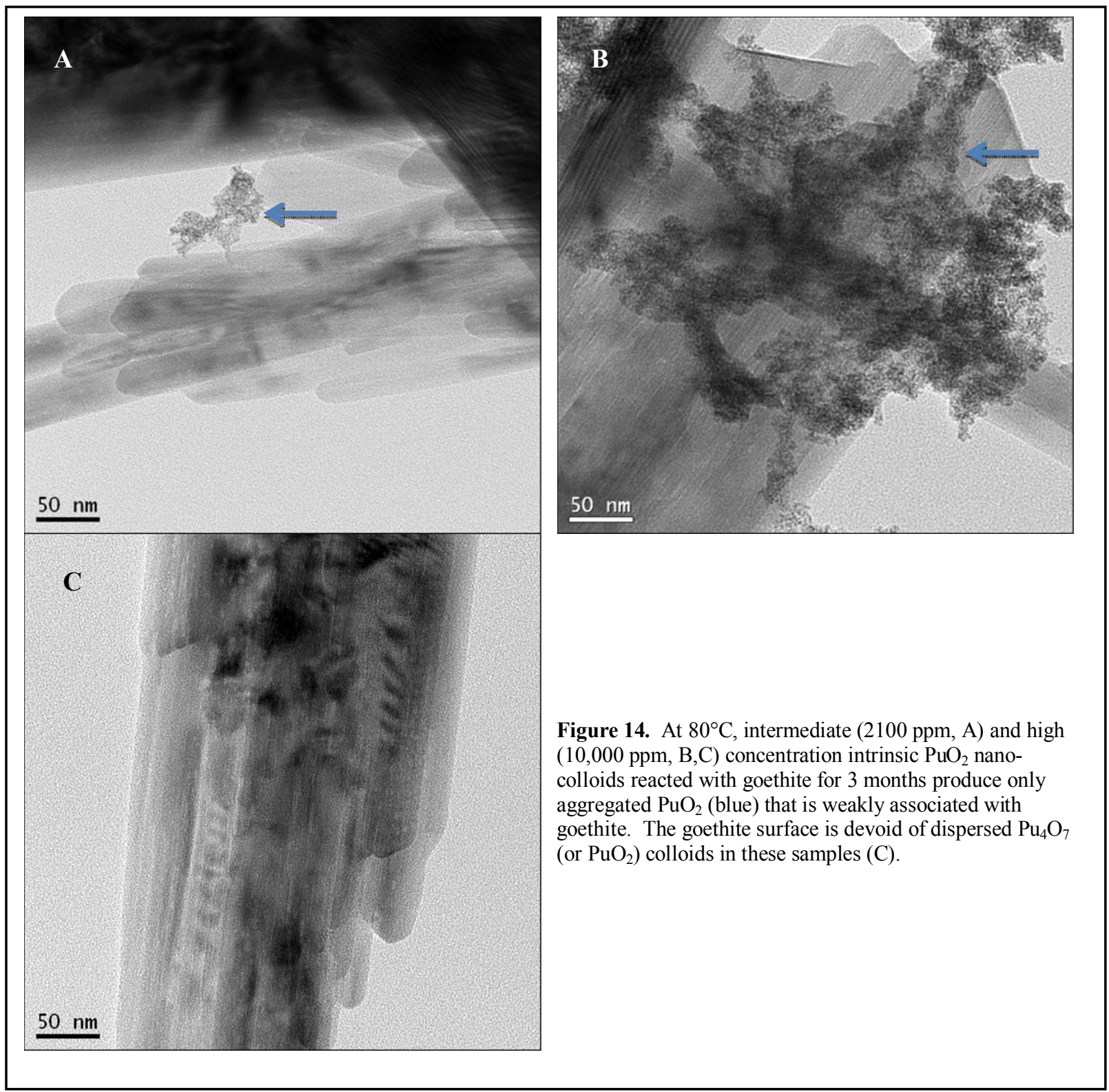

The crystallite size of $\mathrm{PuO}_{2}$ nano-colloids is in the 2-5 nm range and appears to increase only slightly at higher temperatures and over time, consistent with earlier characterization of plutonium sols performed by Haire et al. (1971). Aggregation of $\mathrm{PuO}_{2}$ nano-colloids is favored over sorption to goethite. From a bulk solution perspective, this would be characterized as precipitation and is in agreement with solubility measurements of Neck et al. (2007) for $\mathrm{PuO}_{2}(\mathrm{am}$, hyd). Importantly, a truly amorphous precipitate does not form. The nano-clusters identified in Soderholm et al. (2007) represent the lower limit of colloid sizes observed here by TEM. However, the exact relationship and relative stability of nano-clusters to the larger nano-colloids observed here requires further study. In addition, the relationship between these TEM observations and the bulk characterization of $\mathrm{Pu}$ precipitates with apparent mixed valence (i.e. $\mathrm{PuO} 2+-\mathrm{x}$ ) remains an open question.

The fate of $\mathrm{Pu}$ in the environment is dependent on its initial form and its subsequent stability under changing geochemical conditions. Epitaxial growth of $\mathrm{Pu}_{4} \mathrm{O}_{7}$ on the goethite surface will 
This is a header

produce a strong association between $\mathrm{Pu}$ and goethite, which could lead to it immobilization. However, the weak affinity and stability of intrinsic $\mathrm{Pu}$ colloids in solution and strong and irreversible formation of $\mathrm{Pu}_{4} \mathrm{O}_{7}$ on goethite have the potential to facilitate the transport of $\mathrm{Pu}$ in solution facilitated by colloids.

The focus of ongoing research is on $\mathrm{Pu}$ nanoparticle dissolution kinetics of $\mathrm{Pu}$ nanoparticles and sorbed species from the iron hydroxide. Pu nanoparticle dissolution and $\mathrm{Pu}$ desorption kinetics must be quantified as these rates are likely to control the colloid-facilitated transport of $\mathrm{Pu}$ in the near-field and far-field repository environments. Experimental data summarized in this chapter illustrate the complex reaction chemistry that will control kinetics and the need for a comprehensive conceptual understanding of the underlying mechanisms controlling $\mathrm{Pu}$ reactive transport.

\subsection{Acknowledgements}

This work was performed with funding from the Department of Energy, Nuclear Energy Used Fuel Disposition Program. This work performed under the auspices of the U.S. Department of Energy by Lawrence Livermore National Laboratory under Contract DE-AC52-07NA27344.

\subsection{References}

Bertetti, F.P., Pabalan, R.T., Almendarez, M.G., 1998. Studies on neptunium(V) sorption on quartz, clinoptilolite, montmorillonite, and a-alumina, in: Jenne, E.A. (Ed.), Adsorption of Metals by Geomedia. Academic Press, San Diego, pp. 131-148.

Conradson, S.D., Begg, B.D., Clark, D.L., den Auwer, C., Ding, M., Dorhout, P.K., EspinosaFaller, F.J., Gordon, P.M., Haire, R.G., Hess, N.J., Hess, R.J., Keogh, D.W., Morales, L.A., Neu, M.P., Paviet-Hartmann, P., Runde, W., Tait, C.D., Veris, D.K., Villella, P.M., 2004. Local and nanoscale structure and specitation in the $\mathrm{PuO}_{2+x-y}(\mathrm{OH})_{2 \mathrm{y}}{ }^{*} \mathrm{zH}_{2} \mathrm{O}$ system. J. Amer. Chem. Soc. 126, 13443-13458.

Cvetkovic, V., 2000. Colloid-facilitated tracer transport by steady random ground-water flow. Physics of Fluids 12, 2279-2294.

Cvetkovic, V., Painter, S., Turner, D., Pickett, D., Bertetti, P., 2004. Parameter and model sensitivities for colloid-facilitated radionuclide transport on the field scale. Water Resources Research 40.

Gee, G.W., Bauder, J.W., 1986. Particle-size Analysis, in: Klute, A. (Ed.), Methods of Soil Analysis: Part I - Physical and Mineralogical Methods. American Society of Agronomy, Inc, Madison, WI, pp. 383-411.

Guillaumont, R., Fanghanel, T., Neck, V., Fuger, J., Palmer, D.A., Grenthe, I., Rand, M.H., 2003. Update on the Chemical Thermodynamics of Uranium, Neptunium, Plutonium, Americium, and Technetium, in: Agency, O.N.E. (Ed.), Chemical Thermodynamics. Elsevier, Amsterdam.

Haire, R.G., Lloyd, M.H., Beasley, M.L., Milligan, W.O., 1971. Aging of hydrous plutonium dioxide. Jounal of Electron Microscopy 20, 8-16.

Haschke, J.M., Allen, T.H., Morales, L.A., 2000. Reaction of pluonium dioxide with water: Formation and properties of $\mathrm{PuO}_{2+\mathrm{x}}$. Science 287, 285-287.

Kaszuba, J.P., Runde, W.H., 1999. The aqueous geochemistry of neptunium: Dynamic control of soluble concentrations with applications to nuclear waste disposal. Environmental Science \& Technology 33, 4427-4433.

Keeney-Kennicutt, W.L., Morse, J.W., 1985. The redox chemistry of Pu(V)O2+ interaction with common mineral surfaces in dilute solutions and seawater. Geochimica et Cosmochimica Acta 49, 2577-2588.

Kersting, A.B., Efurd, D.W., Finnegan, D.L., Rokop, D.J., Smith, D.K., Thompson, J.L., 1999. Migration of plutonium in ground water at the Nevada Test Site. Nature 397, 56-59. 
This is a header

Kozai, N., Ohnuko, T., Matsumoto, J., Banba, T., Ito, Y., 1996. A study of the specific sorption of neptunium(V) on smectite in low pH solution. Radiochim. Acta 75, 149-158.

Kozai, N., Ohnuky, T., Muraoka, S., 1993. Sorption characteristics of neptunium by sodiumsmectite. J. Nuclear Sci. Tech. 30, 1153-1159.

Lloyd, M.H., Haire, R.G., 1968. A sol-gel process for preparing dense forms of PuO2. Nuclear Applications 5, 114-122.

Lujaniene, G., Motiejunas, S., Sapolaite, J., 2007. Sorption of Cs, Pu and Am on clay minerals. Journal of Radioanalytical and Nuclear Chemistry 274, 345-353.

Missana, T., Garcia-Gutierrez, M., Alonso, U., 2004. Kinetics and irreversibility of cesium and uranium sorption onto bentonite colloids in a deep granitic environment. Applied Clay Science 26, 137-150.

Neck, V., Altmaier, M., Seibert, A., Yun, J.I., Marquardt, C.M., Fanghanel, T., 2007. Solubility and redox reactions of $\mathrm{Pu}(\mathrm{IV})$ hydrous oxide: Evidence for the formation of $\mathrm{PuO} 2+\mathrm{x}(\mathrm{s}$, hyd). Radiochimica Acta 95, 193-207.

Office of Civilian Radioactive Waste Management, 2002. Yucca Mountain Science and Engineering Report: Technical Information Supporting Site Recommendation Consideration. U.S. Department of Energy, pp. Page 4-466.

Penneman, R.A., Paffett, M.T., 2005. An alternative structure of Pu4O9 ("PuO2.25") incorporating interstitial hydroxyl rather than oxide. J. Solid State Chem. 178, 563-566.

Petit, L., Svane, A., Szotek, Z., Temmerman, W.M., 2003. First-principles calculations of $\mathrm{PuO}_{2+-}$ x. Science 301, 498-501.

Powell, B.A., Dai, Z., Zavarin, M., Zhao, P., Kersting, A.B., 2011. Stabilization of Plutonium Nano-Colloids by Epitaxial Distortion on Mineral Surfaces. Environmental Science \& Technology 45, 2698-2703.

Powell, B.A., Fjeld, R.A., Kaplan, D.I., Coates, J.T., Serkiz, S.M., 2004. Pu(V)O2+ adsorption and reduction by synthetic magnetite (Fe3O4). Environmental Science \& Technology 38, 6016-6024.

Powell, B.A., Fjeld, R.A., Kaplan, D.I., Coates, J.T., Serkiz, S.M., 2005. Pu(V)O2+ adsorption and reduction by synthetic hematite and goethite. Environmental Science \& Technology 39, 2107-2114.

Powell, B.A., Kersting, A.B., Zavarin, M., 2008. Sorption and Desorption Rates of Neptunium and Plutonium on Goethite, in: Zavarin, M., Kersting, A.B., Lindvall, R.E., Rose, T.P. (Eds.), Hydrologic Resources Management Program and Underground Test Area Project, FY 2006 Progress Report. Lawrence Livermore National Laboratory, Livermore, CA, pp. 90, UCRL-TR-404620.

Sabodina, M.N., Kalmykov, S.N., Sapozhnikov, Y.A., Zkharova, E.V., 2006. Neptunium, plutonium and ${ }^{137} \mathrm{Cs}$ sorption by bentonite clays and their speciation in pore waters. J. Radioanal. Nucl. Chem. 270, 349-355.

Saiers, J.E., Hornberger, G.M., 1996. The role of colloidal kaolinite in the transport of cesium through laboratory sand columns. Water Resources Research 32, 33-41.

Sanchez, A.L., Murray, J.W., Sibley, T.H., 1985. The adsorption of plutonium IV and V on goethite. Geochimica et Cosmochimica Acta 49, 2297-2307.

Schwertmann, U., Cornell, R., M., 1991. Iron oxides in the laboratory: preparation and characterization. VCH Verlagsgesellschaft $\mathrm{mbH}$, Weinheim.

Soderholm, L., Almond, P.M., Skanthakumar, S., Wilson, R.E., Burns, P.C., 2008. The structure of the plutonium oxide nanocluster [Pu38O56Cl54(H2O)(8)](14-). Angewandte ChemieInternational Edition 47, 298-302.

Steefel, C.I., 2008. Geochemical kinetics and transport, in: Brantley, S.L., Kubicki, J.D., White, A.F. (Eds.), Kinetics of Water-Rock Interaction. Springer, New York, pp. 545-585. 
This is a header

Tinnacher, R.M., Zavarin, M., Powell, B.A., Kersting, A.B., 2011. Kinetics of neptunium(V) sorption and desorption on goethite: An experimental and modeling study. Geochimica Et Cosmochimica Acta 75, 6584-6599.

Turner, D.R., Pabalan, R.T., Bertetti, F.P., 1998. Neptunium(V) sorption on montmorillonite: An experimental and surface complexation modeling study. Clays and Clay Minerals 46, 256-269.

Zhao, P., Zavarin, M., Tumey, S., Williams, R., Dai, Z., Kips, R., Kersting, A.B., 2010. Isotherm of $\mathrm{Pu} / \mathrm{Goethite}$ System: Linearity and Sorbent Surface Characterization, AGU Fall Meeting, San Francisco. 